\title{
Inclusão: A luta da comunidade surda e dos profissionais intérpretes de Libras
}

\author{
Inclusion: The struggle of the deaf community ando f professionals interpreters of Libras \\ Inclusión: La lucha de la comunidad sordo y los intérpretes profesionales de Libras
}

Recebido: 09/08/2021 | Revisado: 13/08/2021 | Aceito: 15/08/2021 | Publicado: 17/08/2021

Nivaldo de Oliveira Boaventura Filho
ORCID: https://orcid.org/0000-0003-3229-2071
Instituto Federal de Educação, Ciência e Tecnologia do Norte de Minas Gerais, Brasil
E-mail: nivaldo.filho@ifnmg.edu.br
Luidy Siqueira Santos
ORCID: https://orcid.org/0000-0003-3623-2498
Universidade Federal de Minas Gerais, Brasil
E-mail: luidyagri2016@gmail.com
Lilian Simone Godoy Fonseca
ORCID: https://orcid.org/0000-0002-8079-7405
E-mail: lilian.simone@gmail.com

\begin{abstract}
Resumo
O presente artigo trata da educação de surdos e da importância do reconhecimento da Língua Brasileira de Sinais LIBRAS para tal, já que a língua é pressuposto para o pensamento, para a inclusão e, mais além, para o sentido de existência. A história da inclusão traz avanços e retrocessos, conforme o relato de um deficiente visual, citado no estudo, ao dizer das diferenças da escola especial e escola regulares. Muitas outras mudanças incluem o profissional tradutor/intérprete de Libras, com relação às confusões a respeito das funções e responsabilidades dos mesmos, os avanços e retrocessos nas legislações, como a extinção da carreira nas unidades federais, a precarização no atendimento aos alunos, as questões éticas, ergonômicas e formativas da profissão. Ficou demonstrado, pela pesquisa realizada nas instituições de ensino superior da rede federal presentes no Estado de Minas Gerais, o quanto é defasado e demandado o quadro de intérpretes nessas instituições, para que a inclusão ocorra de forma satisfatória.
\end{abstract}

Palavras-chave: Surdo; Língua brasileira de sinais; Intérprete de libras; Inclusão.

\begin{abstract}
This article deals with the education of the deaf and the importance of recognizing the Brazilian Sign Language LIBRAS for this, since language is a prerequisite for thinking, for inclusion and, beyond that, for the meaning of existence. The history of inclusion brings advances and setbacks, according to the report of a visually impaired person, mentioned in the study, when talking about the differences between the special school and the regular school. Many other changes include the professional translator/interpreter from Libras, with regard to confusion about their roles and responsibilities, advances and setbacks in legislation, such as the extinction of careers in federal units, precariousness in student service, issues ethical, ergonomic and formative aspects of the profession. It was demonstrated, by the research carried out in higher education institutions of the federal network present in the State of Minas Gerais, how much is outdated and demanded the staff of interpreters in these institutions, so that the inclusion occurs in a satisfactory way.
\end{abstract}

Keywords: Deaf; Brazilian sign language; Libras interpreter; Inclusion.

\section{Resumen}

Este artículo trata sobre la educación de los sordos y la importancia de reconocer la Lengua de Signos Brasileña LIBRAS para esto, ya que el lenguaje es un requisito previo para el pensamiento, para la inclusión y, más allá, para el sentido de la existencia. La historia de la inclusión trae avances y retrocesos, según el informe de una persona con discapacidad visual, mencionada en el estudio, al hablar de las diferencias entre la escuela especial y la escuela regular. Muchos otros cambios incluyen al traductor / intérprete profesional de Libras, en cuanto a confusión en cuanto a sus roles y responsabilidades, avances y retrocesos en la legislación, como la extinción de carreras en unidades federales, precariedad en el servicio estudiantil, cuestiones éticas, ergonómicas y formativas. de la profesión. Se demostró, mediante la investigación realizada en instituciones de educación superior de la red federal presentes en el Estado de Minas Gerais, cuánto está desactualizado y demandado el personal de intérpretes en estas instituciones, para que la inclusión se dé de manera satisfactoria.

Palabras clave: Sordo; Lengua de señas brasileña; Intérprete de libras; Inclusión. 


\section{Introdução}

A literatura e a linguística estão intimamente ligadas às Ciências Humanas e contemplam também as línguas de sinais, como formas de registro e comunicação de um povo. Assim, ao falar sobre a aprendizagem de novas línguas, novas tecnologias e ensino de línguas, formação docente, estudo do texto e do discurso, trouxemos aqui, de forma breve, o histórico da Língua Brasileira de Sinais, da Educação de surdos e das dificuldades enfrentadas por professores, mas, mais ainda, por um outro profissional: o tradutor/intérprete de Libras.

Durante muito tempo, ser "deficiente"1 era motivo de ser excluído, no Brasil, ou em qualquer parte do mundo. Desde as narrativas bíblicas, é possível perceber como essas pessoas (as não consideradas perfeitas fisicamente) eram tratadas pelas famílias e pela sociedade. Segundo Araújo, “ao longo da história, as pessoas com necessidades especiais foram vistas como incapazes de realizarem atividades que pessoas ditas como "normais" realizavam. Os mesmos foram então excluídos da sociedade e seus direitos, principalmente os de acesso ao trabalho e educação". (Araújo, 2015, p. 153).

Além de crenças e superstições as mais variadas, essas pessoas também foram submetidas aos mais diversos e questionáveis experimentos médicos e científicos e, inclusive, crueldades, como a descrita a seguir: "A infortunada criança era prontamente asfixiada ou tinha sua garganta cortada ou era lançada de um precipício para dentro das ondas. Era uma traição poupar uma criatura de quem a nação nada poderia esperar" (Berthier, 1984, p.165 apud Strobel, 2009, p.16.) Se não, eram retiradas do convívio social pelas próprias famílias, por serem considerados inferiores ou "doidos", motivo de vergonha. Caminhou-se muito até se entender a surdez como diferença, como identidade cultural própria. É o que confirma a fala de Monteiro: "Em décadas passadas, existiam famílias ouvintes que "escondiam" os filhos surdos pela "vergonha" de ter concebido uma criança fora dos padrões considerados normais; e por isso os surdos quase não saíam de casa ou sempre ficavam acompanhados dos pais". (Monteiro, 2006, p. 294).

Esse tipo de atitude vem do conceito de normal/anormal, construído a partir de uma leitura capitalista, ainda utilizado por membros da sociedade, e que foi a base do Congresso de Milão (1880), a ser citado adiante. Segundo Baalbaki e Caldas,

Assim como a categoria normal, uma construção social e, por conseguinte, histórica, a categoria anormal é produzida, em cada período histórico, e legitimada pelo exercício de determinados poderes. Se outrora a anormalidade estava vinculada ao campo do sobrenatural, com o desenvolvimento da ciência moderna (BUENO, 2006) esta categoria passou à intervenção controlada, tendo como base o paradigma biológico. Podemos observar, na forma como funcionava a intervenção, o que Foucault (2010) designa de "poder de normalização". (Baalbaki \& Caldas, 2011, p. 1888).

Essa dualidade normal/anormal, que sempre deve ser questionada por cada cidadão, conforme dito acima, tem sua origem no sistema capitalista, e conforme Foucault:

O capitalismo, desenvolvendo-se em fins do século XVIII e início do século XIX, socializou um primeiro objeto que foi o corpo enquanto força de produção, força de trabalho. O controle da sociedade sobre os indivíduos não se opera simplesmente pela consciência ou pela ideologia, mas começa no corpo, com o corpo. Foi no biológico, no somático, no corporal que, antes de tudo, investiu a sociedade capitalista. O corpo é uma realidade biopolítica. A medicina é uma estratégia biopolítica. (Foucault, 2006, p. 80, apud Baalbaki \& Caldas, 2011, p. 1887).

Por essa razão, eram considerados inúteis, incapazes e, principalmente, invisíveis e estavam à parte de vários espaços de convivência social. O fato de não ouvirem, leva a muitos surdos a não desenvolverem a própria fala, o que não significa que sejam mudos. O termo ‘surdo-mudo’ não é, portanto, apropriado na grande maioria dos casos. Muitos surdos emitem sons incompreensíveis, e até gritos, sem saber que o fazem exatamente por serem surdos. Oficialmente, a Língua Brasileira de Sinais

\footnotetext{
${ }^{1}$ Entre aspas porque não é este o termo que foi utilizado ao longo da história. Atualmente é preferível dizer "pessoa com necessidade específica".
} 
(e daí o nome Libras) só passou a existir em 2002, com a lei 10.436, de 24 de abril². Embora essa informação não seja constitucionalizada, informalmente, a Libras é considerada a segunda língua oficial do Brasil.

Conforme Ferreira et al,

A Libras utiliza movimentos gestuais ${ }^{3}$ e expressões faciais que são captados pelos olhos, caracterizando, assim, sua natureza gestual e visual. As línguas orais, como a língua portuguesa, por outro lado, fazem uso da emissão e captação de sons articulados, caracterizando, diferentemente da Libras, sua natureza oral e auditiva. Todavia, apesar da natureza diferenciada, ambas as línguas cumprem uma mesma função: a comunicação (Dizeu; Caporali, 2005 apud Ferreira et al, 2014, p. 186).

Para os mesmos autores, o seu reconhecimento por meio da lei permite ao povo surdo acesso a um mundo bastante vasto:

Esse reconhecimento da Libras como meio de comunicação e de expressão traz à maioria dos surdos a oportunidade de acesso ao conhecimento de si mesmo, do outro, do mundo, da arte, da ciência, uma vez que por meio dela os surdos desenvolvem sua cognição. Como afirma Vygotsky (2000), língua e pensamento caminham juntos, um depende do outro para coexistir. (Ferreira et al, 2014, p. 186).

Como visto, a Libras é brasileira, e não universal, como erroneamente é entendido por muitos. Apresenta inclusive "sotaques" e regionalismos, como numa língua oral. Cada país possui sua língua de sinais. Há, no entanto, um caminho para uma língua única de sinais internacional, artificial, o estuno.

Consideram-se "artificiais" as línguas construídas e estabelecidas por um grupo de indivíduos com algum propósito específico. O esperanto (língua oral) e o gestuno (língua de sinais) são exemplos de línguas artificiais cujo objetivo maior é estabelecer a comunicação internacional. Esse tipo de língua funciona como uma língua auxiliar ou franca. O gestuno, também conhecido como língua de sinais internacional, é, [...] uma língua construída, planejada. O nome é de origem italiana e significa "unidade em língua de sinais". (Gesser, 2009, p. 12-13).

No entanto, até ser difundida em todo o território nacional e ser compreendida como língua, nesses 18 anos (caminho que não está completo), diante de mais de 500 anos de história do Brasil, o caminho não foi fácil. É o que diz o excerto abaixo, do artigo de Monteiro:

Por muitos anos, os próprios surdos não compreenderam a importância da comunicação através da Língua de Sinais para o processo de construção de sua Identidade Cultural, bem como para o desenvolvimento de sua cognição e linguagem. Consequentemente, o bloqueio no desenvolvimento da Língua de Sinais causou problemas sociais, emocionais e intelectuais na aquisição da linguagem nos surdos. Além disso, esses indivíduos também não conseguiam alcançar suas metas e seus objetivos devido ao preconceito e a marginalização existente na Sociedade, [...]. Ultimamente, observa-se um processo de mudança significativa do olhar da sociedade em relação à questão do Surdo, sua língua e cultura. Entretanto, esse é ainda um processo muito lento dentro das políticas educacionais da sociedade brasileira. Há poucos anos atrás a Língua de Sinais Brasileira era ainda vista como "tabu”, pois não havia sido atribuída a língua de sinais o status de língua. Essa era apenas considerada como "Linguagem" e não "Língua". (Monteiro, 2006, p. 294).

A língua de sinais não é uma "linguagem”, que pode ser construída artificialmente - como é o caso das linguagens de programação de computadores. As linguagens podem ser orais, visuais, uma forma mais geral de defini-las, mas língua tem um conceito diferente. A linguagem também pode ser formal, coloquial, como variações de uma língua, e por isso não são conceitos

\footnotetext{
${ }^{2}$ Por este motivo, 24 de abril é considerado o dia da Libras.

${ }^{3}$ Denominados "sinais".
} 
equivalente. Assim, a Libras é uma Língua, com gramática própria, que não se utiliza de gestos e nem de mímica e nem tão somente do alfabeto manual, e nem é derivada do português ou uma mera tradução. Segundo Pinheiro, no caso da Libras, o:

(...) canal perceptual é diferente, por ser uma língua de modalidade gestual visual, a mesma não teve sua origem da língua portuguesa; que é constituída pela oralidade, portanto considerada oral-auditiva; mas em uma outra língua de modalidade gestual visual, a Língua de Sinais Francesa, apesar de a Língua Portuguesa ter influenciado diretamente a construção lexical da Língua de Brasileira de Sinais, mas apenas por meio de adaptações por serem línguas em contato (Albres, 2005, p.1 apud Pinheiro, 2017, p. 55).

Dito isso, é importante saber que a língua de sinais brasileira tem origem na língua de sinais francesa:

Em 1856, chegou ao Brasil o professor Ernest Huet, surdo francês que trouxe o alfabeto manual francês e alguns sinais para o Brasil. Os surdos brasileiros, que deviam usar algum sistema de sinais próprio, em contato com a Língua de Sinais Francesa (LSF), produziram a Língua de Sinais Brasileira. No ano seguinte, no dia 26 de setembro ${ }^{4}$ de 1857 , foi fundado o Instituto dos Surdos-Mudos do Rio de Janeiro, e denominado o atual Instituto Nacional de Educação de Surdos (INES). (Monteiro, 2006, p. 296).

A criação do INES foi um importante passo para socialização e valorização dos surdos e de sua língua natural, a Libras.

\subsection{Educação de surdos}

A pesquisadora surda Dra. Karin Strobel, afirma que a educação formal dos surdos começou a acontecer de fato, na Idade Moderna, próximo da colonização europeia:

Girolamo Cardano (1501-1576) era médico filósofo que reconhecia a habilidade do surdo para a razão, afirmava que “...a surdez e mudez não é o impedimento para desenvolver a aprendizagem e o meio melhor dos surdos de aprender é através da escrita... e que era um crime não instruir um surdo-mudo.” Ele utilizava a língua de sinais e escrita com os surdos.

O monge beneditino Pedro Ponce de Leon (1510-1584), na Espanha, estabeleceu a primeira escola para surdos em um monastério de Valladolid, inicialmente ensinava latim, grego e italiano, conceitos de física e astronomia aos dois irmãos surdos, Francisco e Pedro Velasco, membros de uma importante família de aristocratas espanhóis; Francisco conquistou o direito de receber a herança como marquês de Berlanger e Pedro se tornou padre com a permissão do Papa. Ponce de Leon usava como metodologia a dactilologia, escrita e oralização. Mais tarde ele criou escola para professores de surdos. Porém ele não publicou nada em sua vida e depois de sua morte o seu método caiu no esquecimento porque a tradição na época era de guardar segredos sobre os métodos de educação de surdos. Nesta época, só os surdos que conseguiam falar tinham direito à herança. (Strobel, 2009, p. 19-20).

A partir de então, as escolas e métodos para educação de surdos se disseminaram pelo mundo, utilizando-se da modalidade gestual e da modalidade oral. Nesse desenvolvimento, é importante falar da figura de Thomas Gallaudet, especialmente em 1814, como faz Strobel:

Em Hartford, nos Estados Unidos, o reverendo Thomas Hopkins Gallaudet (1787-1851) observava as crianças brincando no seu jardim quando percebeu que uma menina, Alice Gogswell, não participava das brincadeiras por ser surda e era rejeitada das demais crianças. Gallaudet ficou profundamente tocado pelo mutismo da Alice e pelo fato de ela não ter uma escola para freqüentar, pois na época não havia nenhuma escola de surdos nos Estados Unidos. Gallaudet tentou ensinar-lhe pessoalmente e juntamente com o pai da menina, o Dr. Masson Fitch Gogswell, pensou na possibilidade de criar uma escola para surdos. O americano Thomas Hopkins Gallaudet parte à Europa para buscar métodos de ensino aos surdos. [...] Thomas Hopkins Gallaudet volta à América trazendo o professor surdo Laurent Clerc, melhor aluno do "Instituto Nacional para Surdos Mudos", de Paris. Durante a travessia de 52 dias na viagem de volta aos Estados Unidos, Clerc ensinou a língua de sinais para Gallaudet que por sua vez lhe ensinou o inglês. Thomas H. Gallaudet, junto com Clerc, fundou em Hartford, 15 de abril, a primeira escola permanente para surdos nos Estados Unidos, “Asilo de Connecticut para Educação e Ensino de pessoas Surdas e Mudas”. Com o sucesso imediato da escola

\footnotetext{
${ }^{4}$ Esse é considerado o dia do surdo no Brasil.
} 
levou à abertura de outras escolas de surdos pelos Estados Unidos, quase todos os professores de surdos já eram usuários fluentes em língua de sinais e muitos eram surdos também. (Strobel, 2009, p. 23-24).

Já citado anteriormente, é importante dar uma atenção ao Congresso de Milão (6 a 11 de setembro de 1880) que, à luz da história, representou um retrocesso para as línguas de sinais e para a comunicação do povo surdo, trazendo resoluções que impactaram até 2010, quando foram rejeitadas no $21^{\circ}$ Congresso Internacional da Educação de Surdos. São algumas das resoluções do Congresso de Milão:

1. O uso da língua falada, no ensino e educação dos surdos, deve preferir-se à língua gestual;

2. O uso da língua gestual em simultâneo com a língua oral, no ensino de surdos, afeta a fala, a leitura labial e a clareza dos conceitos, pelo que a língua articulada pura deve ser preferida;

$[\ldots]$

6. Os surdos, depois de terminado o seu ensino oralista, não esqueceram o conhecimento adquirido, devendo, por isso, usar a língua oral na conversação com pessoas falantes, já que a fala se desenvolve com a prática;

7. A idade mais favorável para admitir uma criança surda na escola é entre os 8-10 anos, sendo que a criança deve permanecer na escola um mínimo de 7-8 anos; nenhum educador de surdos deve ter mais de 10 alunos em simultâneo; 8. Com o objetivo de se implementar, com urgência, o método oralista, deviam ser reunidas as crianças surdas recémadmitidas nas escolas, onde deveriam ser instruídas através da fala; essas mesmas crianças deveriam estar separadas das crianças mais avançadas, que já haviam recebido educação gestual, a fim de que não fossem contaminadas; os alunos antigos também deveriam ser ensinados segundo este novo sistema oral. (Baalbaki \& Caldas, 2011, p. 1892-1893).

Dessa forma, o Congresso de Milão acaba com as línguas visuais-gestuais e impõe à Educação de Surdos a língua oral que, naturalmente, não é a sua língua materna ${ }^{5}$, como se a última fosse superior ou mais pura que a primeira. Skliar (citado por Baalbaki e Caldas) afirma que o Congresso de Milão foi consequência de um pensamento e práticas políticas já existentes e vai além de querer que os surdos sejam como ouvintes. Outros pressupostos contribuíram: “os filosóficos - o oral como abstração, o gestual como sinônimo de obscuridade do pensamento; os religiosos - a importância da confissão oral, e os políticos - a necessidade da abolição dos dialetos, já dominantes no século XVIII e XIX (Skliar, 2010, p. 16-17 apud Baalbaki \& Caldas, 2011, p. 1890).

Karin Strobel divide a história da educação de surdos em três fases, indicadas abaixo:

1. Revelação cultural: Nesta fase os povos surdos não tinham problemas com a educação. A maioria dos sujeitos surdos dominava a arte da escrita e há evidência de que antes do congresso do Milão havia muitos escritores surdos, artistas surdos, professores surdos e outros sujeitos surdos bem-sucedidos.

2. Isolamento cultural: ocorre uma fase de isolamento da comunidade surda em conseqüência do congresso de Milão de 1880 que proíbe o acesso da língua de sinais na educação dos surdos, nesta fase as comunidades surdas resistem à imposição da língua oral.

3. O despertar cultural: a partir dos anos $60^{6}$ inicia uma nova fase para o renascimento na aceitação da língua de sinais e cultura surda após muitos anos de opressão ouvintista para com os povos surdos. (Strobel, 2009, p. 12).

O “despertar cultural” citado pela autora nos faz retomar outras conquistas da educação de surdos e de outros estudantes com necessidades específicas. Cabe-nos falar da comunidade surda, que não é composta só dos próprios surdos, mas dos familiares, amigos e intérpretes de Libras, que deram força a essa luta. Começaram a surgir no Brasil, as escolas de atendimento especializado para deficientes. Escolas só para surdos, só para cegos, só para deficientes físicos, ou para todos eles juntos. Era a segregação muito bem definida. Nas cidades onde não havia essas escolas, também não havia educação para essas pessoas.

\footnotetext{
${ }^{5}$ Língua materna (também língua nativa) é a primeira língua que uma criança aprende e que geralmente corresponde ao grupo étnico-linguístico com que o indivíduo se identifica culturalmente, ou sua primeira língua de comunicação.

${ }^{6}$ A autora refere-se à década de 1960.
} 
Com o tempo, a partir da metade do século XX, houve bastante discussão sobre o "surgimento de propostas, programas e projetos dedicados a uma educação inclusiva e a busca da escola para todos através de Conferências Mundiais como aconteceu em junho de 1994 com a Declaração de Salamanca”. (Araújo, 2015, p. 155).

Em junho de 1994, delegados da Conferência Mundial de Educação Especial das Nações Unidas, redigiram a Declaração de Salamanca. (Salamanca, 1994). Segundo Monteiro (2006), “a Declaração de Salamanca (1994) ganha força de implantação no ano de 2000" (p. 299). E:

Duas de suas determinações são importantes de serem destacadas:

As escolas devem ajustar-se a todas as crianças, independentemente das suas condições físicas, sociais, lingüísticas e outras.

b) A escola deve incluir as crianças com deficiência e/ou superdotada, criança da rua ou crianças que trabalham, crianças de populações imigradas ou nômades, crianças de minorias linguísticas, étnicas ou culturais e crianças de áreas ou grupos desfavorecidos ou marginais. (Monteiro, 2006, p. 299).

A Declaração de Salamanca veio retomar algo já dito na Constituição Federal Brasileira de 1988 (art. 208) e na lei de Diretrizes e Bases da Educação Nacional (Lei 9.394/1996), que já tratavam do assunto da igualdade de oportunidades na educação e da inclusão.

Art. 208 (com interpretação do STF). O dever do Estado com a educação será efetivado mediante a garantia de:

III — atendimento educacional especializado aos portadores de deficiência, preferencialmente na rede regular de ensino; $\S 1^{\circ} \mathrm{O}$ acesso ao ensino obrigatório e gratuito é direito público subjetivo.

$\S 2^{\circ} \mathrm{O}$ não oferecimento do ensino obrigatório pelo Poder Público, ou sua oferta irregular, importa responsabilidade da autoridade competente.

$\S 3^{\circ}$ Compete ao Poder Público recensear os educandos no ensino fundamental, fazer-lhes a chamada e zelar, junto aos pais ou responsáveis, pela frequiência à escola. (Presidência da República, Constituição da República Federativa do Brasil in SUPREMO TRIBUNAL FEDERAL).

Art. 58. Entende-se por educação especial, para os efeitos desta Lei, a modalidade de educação escolar oferecida preferencialmente na rede regular de ensino, para educandos com deficiência, transtornos globais do desenvolvimento e altas habilidades ou superdotação. (Redação dada pela Lei nº 12.796, de 2013).

$\S 1^{\circ}$ Haverá, quando necessário, serviços de apoio especializado, na escola regular, para atender às peculiaridades da clientela de educação especial.

$\S 2^{\circ} \mathrm{O}$ atendimento educacional será feito em classes, escolas ou serviços especializados, sempre que, em função das condições específicas dos alunos, não for possível a sua integração nas classes comuns de ensino regular.

$\S 3^{\circ}$ A oferta de educação especial, nos termos do caput deste artigo, tem início na educação infantil e estende-se ao longo da vida, observados o inciso III do art. $4^{\circ}$ e o parágrafo único do art. 60 desta Lei. (Redação dada pela Lei $n^{\circ}$ 13.632, de 2018. Presidência da República, Lei 9.394).

Num movimento grande e ousado, em 24 de abril de 2007, foi editado o Decreto $\mathrm{n}^{\circ}$ 6.094, que dispõe sobre a implementação do Plano de Metas Compromisso Todos pela Educação. Destacamos o inciso IX do artigo $2^{\circ}$ do decreto:

Art. $2^{\circ}$ A participação da União no Compromisso será pautada pela realização direta, quando couber, ou, nos demais casos, pelo incentivo e apoio à implementação, por Municípios, Distrito Federal, Estados e respectivos sistemas de ensino, das seguintes diretrizes:

IX - garantir o acesso e permanência das pessoas com necessidades educacionais especiais nas classes comuns do ensino regular, fortalecendo a inclusão educacional nas escolas públicas. (Presidência da República, Decreto 6.094).

Em 2008, foi lançada a Política Nacional de Educação Especial na Perspectiva da Educação Inclusiva, pela Secretaria de Educação Continuada, Alfabetização, Diversidade e Inclusão - SECADI/MEC, hoje extinta ${ }^{7}$. Essa política pontuava, entre outras questões:

${ }^{7}$ A Secretaria foi extinta a partir da reorganização do MEC no início do governo do presidente Jair Bolsonaro. 
Ao reconhecer que as dificuldades enfrentadas nos sistemas de ensino evidenciam a necessidade de confrontar as práticas discriminatórias e criar alternativas para superá-las, a educação inclusiva assume espaço central no debate acerca da sociedade contemporânea e do papel da escola na superação da lógica da exclusão. A partir dos referenciais para a construção de sistemas educacionais inclusivos, a organização de escolas e classes especiais passa a ser repensada, implicando uma mudança estrutural e cultural da escola para que todos os estudantes tenham suas especificidades atendidas. (MEC/SETEC, 2008, p. 1).

Uma mudança realmente estrutural. Monteiro (2006) destaca que "para muitos, a integração escolar de alunos com deficiência é um forte estímulo ao desenvolvimento do profissionalismo do professor" (p. 299). Na verdade, houve também forte resistência e necessidade de adequação de métodos para inclusão dos novos alunos e de reaprender as práticas.

No entanto, para a grande maioria dos alunos, a transformação foi realmente grandiosa, conforme o depoimento a seguir, de um único aluno, cego, que estudava em escola especial e depois na escola regular:

Falar desse processo de inclusão me deixa feliz porque, em primeiro lugar, porque eu acho importante falar para as pessoas do que é isso, o que é esse processo na nossa vida. Eu acho importante falar para toda a sociedade, para todas as pessoas o quê que isso significa na vida de uma pessoa de repente se sentiu incluída, ou o impacto negativo que causa na vida de alguém que sente excluída. [...] Eu acredito que a inclusão tenha ajudado a educação porque, desde o processo de democratização - e democratização é de fato dar às pessoas o direito de participar, o direito à educação, em que a gente sempre se deparou com entraves, com problemas nesse processo, então, quando a sociedade, quando as políticas públicas, quando a sociedade se abre à inclusão, ela, de alguma forma, ela favorece essa educação [...] Eu falo a partir da minha experiência e a partir do relato de tantas outras pessoas que eu conheço [que] também passaram dificuldades $\mathrm{a}[\mathrm{o}]$ serem incluídas. Quantos de nós não acreditávamos nesse processo? Quantos de nós tínhamos dificuldades para entender o que seria?... As pessoas dentro de uma sala, uma pessoa com deficiência dentro de uma sala de aula que havia várias pessoas que não tinham deficiência, o quanto isso era um anseio, uma vontade de se sentir igual às outras pessoas, mas, ao mesmo tempo, como era difícil pra gente mesmo entender como seria esse processo. A gente, quando é excluído, a gente também se acostuma com a exclusão e a gente vai se fechando tanto, que nem mesmo conseguimos, às vezes, mensurar o quanto isso nos prejudica. O inverso também é verdade, quando você vai sendo incluído, quando você vai tendo a oportunidade de participar da sociedade, participar dos eventos, que fazem acontecer a nossa vida em sociedade, o quanto que isso vai abrindo os nossos horizontes. [...] Eu fiquei totalmente cego aos 12 anos de idade. [...] A gente precisa olhar para esse processo e entender que se algumas pessoas ainda têm resistência quanto à inclusão, e infelizmente [até] professores, e é algo ainda preocupante. No momento em que eu fui me inserir na vida escolar, foi ainda mais difícil, porque a gente não ouvia a expressão inclusão, a gente não ouvia falar que os alunos tinham direito de estar junto com outras pessoas, com outros seres humanos, às vezes, as pessoas entendiam que esses seres humanos tinham que estar separados, numa escola à parte. [...] Eu estudei numa escola onde eu fui aprender o braille, uma instituição que quem mora em Montes Claros conhece, é uma escola que foi classificada como escola especial. Ela atende alunos que têm deficiência e, naquela ocasião, havia surdos, havia também cegos, que estudavam em uma sala. [...] Havia pessoas que tinham deficiência intelectual. [...] A escola confeccionou uma camiseta e [...] as pessoas riam achavam graça, porque aqueles alunos que usavam aquela camiseta eram da escola dos deficientes, [...] e, às vezes, falavam a 'escola dos doidos', a 'escola dos deficientes', 'dos doentes'... Era assim que a gente era visto. Então, quantas vezes, batia vergonha de usar a camiseta, passar na rua e as pessoas te apontarem te apontarem: "olha ele é da escola dos deficientes". Então, tinha uma escola dos deficientes, tinha a escola onde a gente ficava separado. [...] Hoje, olhando o quão seria saudável para mim saber que eu estava numa escola onde era a escola de todo mundo, escola de todos, era a escola que eu queria quando eu tinha 12 anos, quando eu tinha 13 anos, adolescente, que precisava de formar minha autoestima também, de me sentir um ser humano como os demais, não me sentir inferiorizado. Eu queria estar na escola de todos, a escola onde todo mundo tinha direito de participar e hoje eu defendo essa escola. Eu defendo o direito de participarmos, de estarmos juntos, pessoas que têm deficiência ou que não têm deficiência, pessoas negras, pessoas que têm maior dificuldade econômica, enfim, onde todas as pessoas possam estar juntas constituindo essa beleza da sociedade, a beleza de estar junto, a beleza de todos sermos seres humanos, que é isso que somos, estarmos juntos. [...] [Depois,] eu fui passar por uma escola regular [...] e lá eu pude conviver com colegas que não tinham deficiência. Na verdade, deficiente visual eu era o único da sala. Certamente [tinham] outras deficiências que não as que a gente caracteriza como: cego, surdo, cadeirante... Enfim, mas as deficiências que cada um trazemos dentro de nós. [...] Eu pude ver a maravilha que é conviver, mesmo sendo deficiente, com pessoas que não têm deficiência, pessoas que também se abriram a me ajudar. Eu nunca neguei, não nego, eu Fabiano, cego, preciso de ajuda. Certamente, também, posso ajudar muita gente. [...] Se a gente encontra dificuldade, encontra quem discrimine, a gente também encontra pessoas que estão dispostas a ajudar, e eu ainda acredito que o bem, que a vontade de fazer um mundo melhor, uma sociedade melhor, ainda é maior, é nisso que eu preciso acreditar e é nisso que eu te convido a acreditar também. [...] Ao sair de lá, eu continuei a minha trajetória: terminei o ensino médio, fiz curso técnico, [...] estudei no conservatório, estudei música, e fiz a faculdade me formei em música na Unimontes [...] [foi] tudo muito maravilhoso: poder participar, 
ter o direito de fazer parte, de ir ao encontro, de lutar pelos meus sonhos, pelo que eu queria fazer foi muito importante. (Freitas, Fabiano Batista, 2020, in.: IFNMG, canal do Youtube, online).

O depoimento comprova que um novo tempo havia chegado. Novas formas de se sentir, de conviver, de ser profissional, especialmente na educação. É a comprovação do pensamento de Freire, que afirma, sobre as diferenças serem necessárias, ser "uma das raras certezas de que estou certo" (Freire, 2017, p. 119 [1998, p. 108] apud Kohan, 2019, p. 2). Segundo o autor, é preciso tratar "[...] qualidades ou virtudes como amorosidade, respeito aos outros, tolerância, humildade, gosto da alegria, gosto da vida, abertura ao novo, disponibilidade à mudança, persistência na luta, [...] identificação com a esperança, abertura à justiça.” (Freire, 2017, p. 118 [1998, p. 108] apud Kohan, 2019, p. 2).

Refletindo sobre a inclusão (de camponeses, nesse caso), na obra Pedagogia da Esperança, de 1992, podemos nós também pensar a Educação de surdos:

[Freire relata:] Me impressionava, ora quando era informado nas reuniões de avaliação, ora quando presenciava como os camponeses se davam à análise de sua realidade local e nacional. O tempo sem limite de que pareciam precisar para amainar a necessidade de dizer sua palavra. Era como se, de repente, rompendo a "cultura do silêncio", descobrissem que não apenas podiam falar, mas, também, que seu discurso crítico sobre o mundo, seu mundo, era uma forma de refazê-la. Era como se começassem a perceber que o desenvolvimento de sua linguagem, dando-se em torno da análise de sua realidade, terminasse por mostrar-lhes que o mundo mais bonito a que aspiravam estava sendo anunciado, de certa forma antecipado, na sua imaginação. E não vai nisto nenhum idealismo. A imaginação, a conjectura em torno do mundo diferente do da opressão, tão necessários aos sujeitos históricos e transformadores da realidade para sua práxis, quanto necessariamente faz parte do trabalho humano que o operário tenha antes na cabeça o desenho, a "conjectura" do que vai fazer. Aí está uma das tarefas da educação democrática e popular, da Pedagogia da esperança - a de possibilitar nas classes populares o desenvolvimento de sua linguagem, jamais pelo blablablá autoritário e sectário dos "educadores", de sua linguagem, que, emergindo da e voltando-se sobre sua realidade, perfile as conjecturas, os desenhos, as antecipações do mundo novo. Está aqui uma das questões centrais da educação popular - a da linguagem como caminho de invenção da cidadania. (Freire, 1992, p. 20).

\subsection{A profissão do intérprete e o intérprete educacional}

Antes de tratar do tema a que se refere essa seção, é importante deixar claro a diferença entre tradutor e intérprete, conforme faz Valente:

Costuma-se associar a figura do tradutor à do intérprete, como se desempenhassem o mesmo trabalho. Não raro, são encontradas menções ao "tradutor-intérprete" de Libras como a figura - observe bem que se fala de "a figura" e não "as figuras". O responsável por verter em Língua Brasileira de sinais a língua portuguesa (ou outro idioma) e vice-versa. [...] "Os intérpretes existem desde a Antiguidade, assim como os tradutores, com quem são frequentemente confundidos; o tradutor trabalha com a palavra escrita, o intérprete com a palavra falada". Assim começa o livreto da União Europeia (Comission of the European Communities, s/d). (Pagura, 2003, p. 2010, apud Rodrigues E Valente, p. 14) [...] O tradutor trabalha com o texto escrito e o resultado de sua tradução é um "outro" escrito; o intérprete lida com a fala e o resultado de seu trabalho é uma "outra fala". Transpondo tal conceituação para a língua de sinais, deve-se assumir que o profissional responsável por transpor discursos falados para Libras, ou o contrário, é o intérprete. Já o que o transpõe um discurso escrito para outro escrito é o tradutor. (Rodrigues E Valente, 2011, p.14).

Há registros de que a profissão do intérprete foi de grande importância durante a Primeira Guerra Mundial (1914-1918). Anteriormente, as negociações e conferências eram realizadas em Francês. No entanto, com a entrada dos Estados Unidos e da Inglaterra na guerra e nas conferências, "torna-se necessária a interpretação entre inglês e francês, uma vez que alguns dos representantes americanos, como também os da Inglaterra, não falavam francês com a fluência necessária para as negociações”. (Pagura, 2003, p. 213). Segundo o sítio VOX Intérpretes, que oferece serviços de interpretação, "Ser intérprete de guerra é tarefa de alto risco e muita coragem. [...] Entre os soldados de língua inglesa, os responsáveis por fazer a ponte entre os diferentes idiomas envolvidos são conhecidos como “terps” (abreviação da palavra “interpreters”)". (VOX, 2016, online).

Segundo Pagura, 
Ao final da Segunda Guerra, com o advento do Julgamento de Nuremberg dos criminosos de guerra alemães, surge o problema de realizar um julgamento com quatro línguas principais: inglês, francês, russo e alemão. A consecutiva seria impensável, pois alongaria imensamente a duração das sessões do Tribunal, além de dificultar a mecânica de atuação de testemunhas, promotores, advogados, juízes e réus, falantes de diferentes idiomas. Quem recebeu a incumbência de encontrar a solução para o problema foi o Coronel Leon Dostert, intérprete do General Eisenhower. [...] Dostert convoca jovens intérpretes consecutivos e outras pessoas sem experiência em interpretação, mas com excelente competência lingüística e, após alguns meses de experimentação e treinamento intensos, surge o embrião do que viria a ser a interpretação simultânea como a conhecemos hoje em dia (cf.: AIIC 1996; Gaiba 1998, apud Pagura, 2003, p. 214).

Além disso, o mesmo autor menciona também a profissão dos intérpretes desde os tempos bíblicos, e, ainda, na Idade Média e na Idade Moderna, como se vê no trecho a seguir:

A mais antiga referência a um intérprete parece ser um hieróglifo egípcio do terceiro milênio antes de Cristo. Há registros de intérpretes na antiga Grécia e no Império Romano. Na Bíblia, o Apóstolo Paulo faz a seguinte admoestação em sua Epístola aos Coríntios: "E se alguém falar em língua desconhecida, faça-se isso por dois, ou quando muito três, e por sua vez, e haja intérprete" (I Coríntios 14:28). A atuação de intérpretes também está documentada na Idade Média, seja nas Cruzadas ou em encontros diplomáticos. No Novo Mundo, sabe-se que Colombo trouxe intérpretes em sua expedição, ainda que das línguas erradas: hebraico, caldeu e árabe. Mais conhecido e mais bem documentado é o caso de Doña Marina, famosa intérprete de Cortez em sua conquista do México (cf.: Hogg 1997, apud Pagura, 2003, p. 13).

No entanto, no que diz respeito ao movimento educacional da inclusão, do qual falávamos na seção anterior, a profissão intérprete não foi tratada com a seriedade necessária. Com a inclusão dos alunos surdos nas salas de aulas regulares, a demanda por intérpretes aumentou consideravelmente e, como a profissão não era ainda reconhecida, oficializada, diversos profissionais, ainda que com conhecimento precário, candidataram-se às vagas.

Os próprios professores e demais servidores da escola, que não estavam acostumados e preparados para a mudança, sentiram dificuldades, ainda mais os surdos, que deveriam sentir-se incluídos, mas não tinham intérpretes totalmente fluentes em suas salas de aula. Muitos viam apenas como uma oportunidade de emprego e os cursos básicos de Libras se multiplicaram, e profissionais com os cursos básicos saíram em busca das vagas.

Apesar da atuação dos CAS - Centros de Capacitação de Profissionais da Educação e de Atendimento às Pessoas com Surdez (CAS), na realização de bancas de avaliação de intérpretes educacionais (em sua maioria para a rede estadual de ensino), muitas cidades não apresentavam profissionais com a fluência necessária, muitas eram as escolas e as turmas e a demanda era grande para as equipes.

Segundo o decreto 5.626/2005 (posterior à Declaração de Salamanca -1994, da Lei de acessibilidade - 2000, da Lei de Libras - 2002, e as mudanças na redação da LDB - 2013 e 2018), ficou regulamentado que (de forma delimitada):

Art. $2^{\circ}$ Para os fins deste Decreto, considera-se pessoa surda aquela que, por ter perda auditiva, compreende e interage com o mundo por meio de experiências visuais, manifestando sua cultura principalmente pelo uso da Língua Brasileira de Sinais - Libras.

Art. 14. As instituições federais de ensino devem garantir, obrigatoriamente, às pessoas surdas acesso à comunicação, à informação e à educação nos processos seletivos, nas atividades e nos conteúdos curriculares desenvolvidos em todos os níveis, etapas e modalidades de educação, desde a educação infantil até à superior.

$\S 1^{\circ}$ Para garantir o atendimento educacional especializado e o acesso previsto no caput, as instituições federais de ensino devem:

III - prover as escolas com:

a) professor de Libras ou instrutor de Libras;

b) tradutor e intérprete de Libras - Língua Portuguesa;

c) professor para o ensino de Língua Portuguesa como segunda língua para pessoas surdas; e

d) professor regente de classe com conhecimento acerca da singularidade lingüística manifestada pelos alunos surdos; Art. 17. A formação do tradutor e intérprete de Libras - Língua Portuguesa deve efetivar-se por meio de curso superior de Tradução e Interpretação, com habilitação em Libras - Língua Portuguesa.

Art. 18. Nos próximos dez anos, a partir da publicação deste Decreto, a formação de tradutor e intérprete de Libras Língua Portuguesa, em nível médio, deve ser realizada por meio de: 
I - cursos de educação profissional;

II - cursos de extensão universitária; e

III - cursos de formação continuada promovidos por instituições de ensino superior e instituições credenciadas por secretarias de educação.

Parágrafo único. A formação de tradutor e intérprete de Libras pode ser realizada por organizações da sociedade civil representativas da comunidade surda, desde que o certificado seja convalidado por uma das instituições referidas no inciso III.

Art. 20. Nos próximos dez anos, a partir da publicação deste Decreto, o Ministério da Educação ou instituições de ensino superior por ele credenciadas para essa finalidade promoverão, anualmente, exame nacional de proficiência em tradução e interpretação de Libras - Língua Portuguesa.

Art. 21. A partir de um ano da publicação deste Decreto, as instituições federais de ensino da educação básica e da educação superior devem incluir, em seus quadros, em todos os níveis, etapas e modalidades, o tradutor e intérprete de Libras - Língua Portuguesa, para viabilizar o acesso à comunicação, à informação e à educação de alunos surdos.

$\S 1^{\circ} \mathrm{O}$ profissional a que se refere o caput atuará:

I - nos processos seletivos para cursos na instituição de ensino;

II - nas salas de aula para viabilizar o acesso dos alunos aos conhecimentos e conteúdos curriculares, em todas as atividades didático-pedagógicas; $\mathrm{e}$

III - no apoio à acessibilidade aos serviços e às atividades-fim da instituição de ensino.

Art. 26. A partir de um ano da publicação deste Decreto, o Poder Público, as empresas concessionárias de serviços públicos e os órgãos da administração pública federal, direta e indireta devem garantir às pessoas surdas o tratamento diferenciado, por meio do uso e difusão de Libras e da tradução e interpretação de Libras - Língua Portuguesa, realizados por servidores e empregados capacitados para essa função, bem como o acesso às tecnologias de informação, conforme prevê o Decreto no 5.296 , de 2004.

$\S 1^{\circ}$ As instituições de que trata o caput devem dispor de, pelo menos, cinco por cento de servidores, funcionários e empregados capacitados para o uso e interpretação da Libras.

Art. 26. O Poder Público, as empresas concessionárias de serviços públicos e os órgãos da administração pública federal, direta e indireta, deverão garantir às pessoas surdas ou com deficiência auditiva o seu efetivo e amplo atendimento, por meio do uso e da difusão da Libras e da tradução e da interpretação de Libras - Língua Portuguesa. (Redação dada pelo Decreto ${ }^{\circ}$ 9.656, de 2018).

Art. 27. No âmbito da administração pública federal, direta e indireta, bem como das empresas que detêm concessão e permissão de serviços públicos federais, os serviços prestados por servidores e empregados capacitados para utilizar a Libras e realizar a tradução e interpretação de Libras - Língua Portuguesa estão sujeitos a padrões de controle de atendimento e a avaliação da satisfação do usuário dos serviços públicos, sob a coordenação da Secretaria de Gestão do Ministério do Planejamento, Orçamento e Gestão, em conformidade com o Decreto no 3.507, de 13 de junho de 2000.

Art. 29. O Distrito Federal, os Estados e os Municípios, no âmbito de suas competências, definirão os instrumentos para a efetiva implantação e o controle do uso e difusão de Libras e de sua tradução e interpretação, referidos nos dispositivos deste Decreto.

Art. 30. Os órgãos da administração pública estadual, municipal e do Distrito Federal, direta e indireta, viabilizarão as ações previstas neste Decreto com dotações específicas em seus orçamentos anuais e plurianuais, prioritariamente as relativas à formação, capacitação e qualificação de professores, servidores e empregados para o uso e difusão da Libras e à realização da tradução e interpretação de Libras - Língua Portuguesa, a partir de um ano da publicação deste Decreto. Art. 31. Este Decreto entra em vigor na data de sua publicação.

Brasília, 22 de dezembro de 2005. (Presidência da República, Decreto 5.626).

O atendimento do decreto 5.626/2005 vem sendo constantemente discutido pelos profissionais regidos por ele, no que diz respeito à sua atuação nas instituições federais de ensino, percentuais, formação e atividades a serem realizadas, à continuidade e à profissionalização dos servidores efetivos. No entanto, os diretores alegam, com razão, que há falta de recursos e de servidores. Assim, é necessário mais empenho nesta causa pelos ocupantes de cargos de direção, ainda que seja apenas uma das inúmeras questões de uma escola que, de fato, são muito variadas, mas, essa é uma das mais relevantes, como foi relatado no depoimento da seção anterior.

O envolvimento de toda a comunidade é importante porque, em 9 de janeiro de 2018, o então presidente Michel Temer editou o decreto 9.262, que tinha a finalidade de extinguir cargos efetivos que vierem a vagar dos quadros de pessoal da administração pública federal, e veda a abertura de concurso público e o provimento de vagas adicionais para os cargos que especifica. 
Art. $1^{\circ}$ Ficam extintos, no âmbito da administração pública federal direta, autárquica e fundacional, os seguintes cargos efetivos regidos pela Lei $\mathrm{n}^{\circ}$ 8.112, de 11 de dezembro de 1990:

I - vagos e que vierem a vagar constantes dos Anexos I e II; e

II - vagos constantes do Anexo III.

Art. $2^{\circ}$ Ficam vedados para os cargos constantes do Anexo IV:

I- a abertura de concurso público; e

II - o provimento de vagas em quantitativo superior ao estabelecido no edital de abertura do concurso público. (Presidência da República, Decreto 9.262). (Presidência da República, Decreto 9.262).

Na lista do ANEXO I do decreto, seção C, cargos vagos e que vierem a vagar cujo requisito de escolaridade exigido para ingresso é de nível superior, estão os cargos de Tradutor e Tradutor Intérprete, e no ANEXO IV do decreto, dos cargos para os quais ficam vedados a abertura de concurso público e o provimento de vagas adicionais em relação ao previsto no edital, está o de Tradutor Intérprete (Nível E).

Embora em 2020, os profissionais intérpretes tenham comemorado 10 anos da lei que regulamentava a sua profissão, desempenhada inclusive pela atual primeira-dama, Michele Bolsonaro (que, em $1^{\circ}$. de janeiro de 2019, atuou como intérprete de Libras no discurso de posse, do Presidente da República), por meio do Decreto 10.185, de 20 de dezembro de 2019, foi extinta a SECADI, e em seguida, a previsão de provimento de vagas de intérpretes de Libras.

Extingue cargos efetivos vagos e que vierem a vagar dos quadros de pessoal da administração pública federal e veda a abertura de concurso público e o provimento de vagas adicionais para os cargos que especifica.

Art. $1^{\circ}$ Ficam extintos, no âmbito da administração pública federal direta, autárquica e fundacional, os cargos efetivos regidos pela Lei ${ }^{\circ} 8.112$, de 11 de dezembro de 1990:

I - vagos e que vierem a vagar constantes do Anexo I; e

II - vagos constantes do Anexo II.

Art. $2^{\circ}$ Ficam vedados a abertura de concurso público e o provimento de vagas adicionais em quantitativo superior ao estabelecido em edital de abertura de concurso público para os cargos constantes do Anexo III. (Presidência da República, Decreto 10.185).

O cargo de Tradutor e Intérprete de Linguagem de Sinais (de nível médio - D), é localizado no anexo III, e o cargo de Tradutor e Intérprete (de nível superior - E), é localizado no anexo I. É como se fosse um retorno ao tempo. Na ocasião, a Comunidade Surda do Brasil divulgou uma nota de repúdio, que teve poucos efeitos práticos, mas demonstrou como a medida feria sua dignidade e suas possibilidades de inclusão. Segue a nota, na íntegra:

A Comunidade Surda do Brasil vem a público manifestar repúdio ao Decreto no 10.185, de 20 de dezembro de 2019 do Governo Federal, o qual extingue o cargo de Tradutor/ Intérprete de Libras de caráter efetivo/vagos e que vierem a vagar dos quadros de pessoal da administração pública federal, vedando a abertura de concurso público e o provimento de vagas adicionais para o cargo supracitado e entre outros.

A medida fere a nossa dignidade humana, fragiliza o nosso reconhecimento linguístico, e ameaça, sobretudo, os estados e municípios numa possível desobrigatoriedade de se responsabilizarem pela garantia legítima dos direitos surdos, através da Lei $\mathrm{n}^{\circ}$ 10.436/02 (Lei da Libras) e do Decreto $\mathrm{n}^{\circ}$ 5.626, de 22 de dezembro de 2005 e seus respectivos dispositivos propostos, que garantem o intérprete de Libras capacitado, em sala de aula.

A indignação deste decreto se estende ao curso de Bacharelado em Letras/ Libras, nas Universidades e Institutos Federais, além dos incontáveis cursos de intérpretes nas capitais e interiores deste país com aspirantes profissionais da área. Todos eles, também, repudiam a medida e prestam solidariedade à nossa comunidade.

Excelentíssimo Sr. Presidente Jair Bolsonaro e sua digníssima primeira-dama, a Sra. Michelle Bolsonaro, nós surdos deste país, não aceitaremos o retrocesso de nossa causa. A nossa História merece respeito, compaixão, e mais responsabilidade. A palavra proferida em seus Discursos de Posse e os votos dos quais muitos de nós lhe confiaram é, hoje - uma traição - que chegou até nós como o presente de Natal mais doloroso que jamais imaginaríamos receber um dia, depois de tantas conquistas.

Vamos à Luta! (Paraíba.COM.BR, 2019, online)

Com o decreto, fica claro o retrocesso que aconteceu porque, a partir de então, não se formariam mais novos tradutoresintérpretes profissionais. 
De modo geral, tanto aqui quanto em como em outros países, a formação de tradutores e intérpretes de línguas de sinais está vinculada à pratica de atividades voluntárias, que, com o decorrer do tempo e com o avanço das conquistas sociais do surdo, foram sendo valorizadas em sua condição trabalhista. Nesse sentido, a luta do surdo por espaços nas esferas sociais, como na educação, no trabalho, na saúde etc., e, principalmente, pelo reconhecimento de sua língua como língua de fato e da qual ele poderia se valer nos espaços conquistados, deflagrou a necessidade pelo Tradutor e Intérprete de Língua de Sinais, uma vez que as instituições precisaram, por uma questão de acessibilidade, que uma ponte fosse estabelecida entre elas e o surdo. (Rodrigues \& Valente, 2011, p 15-16).

Se houve retrocesso para os intérpretes, houve ainda mais para os surdos (levando-se em conta o depoimento do Sr. Fabiano) e os avanços referentes à educação inclusiva. Com a publicação do Decreto 10.502 de 30 de setembro de 2020, e com ela a possibilidade de novas escolas só para deficientes, ou novas classes só para deficientes, ou classes somente bilingues. Com este foco, diferente do que era o conceito de inclusão, muitas escolas regulares passaram a recusar a matrícula de estudantes deficientes. O MEC anunciou que é crime negar a matrícula e que será criado um canal de denúncias. O Supremo Tribunal Federal analisa ação contra o decreto ${ }^{8}$.

Mesmo tendo sido aprovada a "Lei de Libras" em 2002, apenas em $1^{\circ}$ de setembro de 2010, o profissional, antes voluntário, com atendimento até mesmo precário, já tinha seus primeiros ganhos. Porque, conforme Rodrigues e Valente, com a regulamentação advinda do decreto 5.626/2005 houve um avanço na aplicação das políticas linguísticas em relação à Libras, fazendo com que ela alcançasse gradativamente um lugar próprio enquanto objeto de interesse científico, sendo estudada sob perspectivas diversas. O próprio decreto não tratava de alguns assuntos importantes, por ser uma discussão relativamente nova, mas ainda assim foi importante para a abertura de oportunidades no mercado de trabalho. (Rodrigues \& Valente, 2011). A lei que trata da profissão encontra-se atualmente no Senado Federal para apreciação, após ser aprovada pela Câmara dos Deputados com algumas modificações como as citadas abaixo:

Art. $4^{\circ} \mathrm{O}$ exercício da profissão de tradutor, intérprete e guia-intérprete é privativo de:

I - (revogado);

II - (revogado);

III - (revogado);

IV - diplomado em curso de educação profissional técnica de nível médio em Tradução e

Interpretação em Libras;

V - diplomado em curso superior de bacharelado em Tradução e Interpretação em Libras - Língua Portuguesa, Letras com Habilitação em Tradução e Interpretação em Libras ou em Letras - Libras;

VI - diplomado em outras áreas de conhecimento, desde que possua diploma de cursos de extensão, de formação continuada ou de especialização, com carga horária mínima de 360 (trezentas e sessenta) horas e que tenha sido aprovado em exame de proficiência em tradução e interpretação em Libras - Língua Portuguesa; ou

VII - portador de diploma em curso superior em outras áreas de conhecimento, complementado por cursos de extensão, de formação continuada ou de especialização, com carga horária mínima de 360 (trezentas e sessenta) horas, desde que aprovado em exame de proficiência em tradução e interpretação em Libras - Língua Portuguesa.

$\S 1^{\circ}$ (Revogado).

“Art. $8^{\circ}$ - A duração do trabalho dos profissionais de que trata esta Lei será de 6 (seis) horas diárias ou de 30 (trinta) horas semanais.

Parágrafo único. O trabalho de tradução e interpretação superior a 1 (uma) hora de duração deverá ser realizado em regime de revezamento, com, no mínimo, 2 (dois) profissionais. (SENADO FEDERAL, PL 5614 de 2020).

As mudanças destacadas tratam da formação do intérprete (técnica ou superior), que deve ser de acordo com o nível educacional em que irá atuar, conforme aponta Quadros:

Outro aspecto a ser considerado na atuação do intérprete em sala de aula é o nível educacional. O Intérprete de Língua de Sinais poderá estar atuando na educação infantil, na educação fundamental, no ensino médio, no nível universitário e no nível de pós graduação. Obviamente que em cada nível deve-se considerar diferentes fatores. [...] Nos níveis posteriores, o intérprete passa a necessitar de conhecimentos cada vez mais específicos e mais aprofundados para poder

${ }^{8}$ As informações são da Folha de São Paulo, Jornal de Brasília e outros veículos jornalísticos. 
realizar a interpretação com o grau de exigência dos níveis cada vez mais adiantados de escolarização. (QUADROS, 2007, in.: Rodrigues \& Valente, 2011, p. 24).

Ora, a maioria dos cursos das Universidades Federais é de nível superior, incluindo aí os de pós-graduação. Os Institutos Federais também oferecem cursos de nível superior, além dos de nível técnico. A formação do intérprete deveria acompanhar essa exigência interpretativa, porém, não é o que acontece, conforme detalharemos no quadro da seção seguinte. Nesse sentido, existem movimentações e jurisprudência (segundo o sítio Petição Pública e o PL em andamento no Senado Federal) para que o cargo de nível D (médio) seja substituído pelo (superior).

As 30 horas semanais e o revezamento partem da análise do esforço físico e mental do profissional no ato tradutório. A FEBRAPILS - A Federação Brasileira das Associações dos Profissionais Tradutores e Intérpretes e Guia-Intérpretes de Língua de Sinais destaca que:

A Norma Regulamentadora - Ergonomia publicada pelo Ministério do Trabalho (NR17-Ergonomia) em 1990, que visa regulamentar e estabelecer parâmetros que permitam a adaptação das condições de trabalho às características psicofisiológicas dos trabalhadores, de modo a proporcionar um máximo de conforto, segurança e desempenho eficiente, estabelece no item 17.6.3 que devem ser incluídas pausas, "nas atividades que exijam sobrecarga muscular estática ou dinâmica do pescoço, ombros, dorso e membros superiores e inferiores".

Esse intervalo deve ocorrer quando os intérpretes atuam em equipe e realizam o revezamento na produção da interpretação. (Oliveira, Rosa E Santiago 2009), (Braga \& Trindade, 2007) e (Gabrian, Williams 2009).

$\mathrm{O}$ trabalho de interpretação e guia-interpretação quando realizado por apenas uma pessoa durante longos períodos prejudica a qualidade na interpretação, uma vez que, devido ao intenso esforço cognitivo maior número de omissões podem ocorrer e o profissional perde a capacidade de se auto monitorar em sua produção. (Gile, 1995), (Quadros, 2004). Nesse sentido, as pesquisas que vêm sendo desenvolvidas com esses profissionais recomendam a troca entre as funções de uma equipe de intérpretes num período de 20 até 30 minutos. Estudos indicam que esse período é o tempo adequado para a concentração do intérprete, depois desse tempo (20m-30m), inicia-se um processo de fadiga mental que afeta a produção da mensagem.

Quanto mais longa a interpretação mais erros e omissões podem ocorrer. Essa troca é fundamental para garantir permanentemente um nível elevado na qualidade da produção na língua-alvo. (Marcer, Kunzil \& Korac 1998).

Sobre esse ponto, é importante trazer também as considerações do trabalho monográfico do Curso de Letras Libras da UFSC, desenvolvido por Licia Maria Cardoso Azevedo, em 2018, e com o título "Saúde Ocupacional e Ergonomia na atuação do Tradutor Intérprete de Libras", tratando do assunto:

Os TILS educacionais frequentemente desenvolvem suas atividades sem revezamento já que a legislação atual não contempla esse aspecto da profissão. [...] A atividade interpretativa quando realizada de forma individual pode causar danos à saúde do TILS, Bauk (2008) afirma que manipular os braços na horizontal, permanecer em pé ou sentado por longos períodos se caracterizam como trabalho estático e que o mesmo "além de fadiga e dores musculares, os esforços estáticos repetidos e prolongados podem levar a inflamações, bainhas, e inserções tendíneas, bem como originar sintomas de degeneração articular crônica e problema discais" (Bauk, 2008, p.115). Atuando sozinho o TILS pode, decorrido certo tempo de intensa atividade tradutória, experimentar sensações de cansaço e em virtude disso, processar informações de forma imprecisa já que a capacidade de agrupamento de processos mentais do profissional é consideravelmente afetada devido à fadiga muscular, que o autor define como: Uma manifestação aguda e dolorosa, localizada em músculos excessivamente solicitados, acompanhada de acúmulo de resíduos metabólicos, como ácido lático e o dióxido de carbono. [...] (Bauk, p.199. 2008).

A ação de traduzir e interpretar envolve processos linguísticos altamente complexos e por isso demanda do profissional tradutor intérprete uma intensa atividade mental e atenção constante durante todo o processo tradutório. [...] A atividade do TILS, desse modo se revela de intensa e complexa atividade mental, pois informações recebidas precisam ser continuamente processadas para a realização da tradução e interpretação exigindo alto nível de criatividade. [...] A atividade tradutória envolve processamento de informações para tomada de decisões, ou seja, todas as informações recebidas pelo TILS na língua fonte necessitam ser processadas e o profissional precisa, fazendo uso de suas competências, tomar decisões sobre qual termos utilizar na língua alvo e tudo isso em apenas alguns segundos, em virtude disso o TILS deve durante sua atividade armazenar informações, processá-las, recuperá-las quando necessário (fazendo uso da memória de curta e longa duração) e produzir essas mesmas informações na língua alvo, para tanto, 
esse profissional deve manter uma atenção prolongada durante toda a realização de sua atividade. (Azevedo, 2018, p. $23-24$, p. 25-26)

A questão da tradução, como complexa atividade mental, é trazida também por Rodrigues e Valente, pois, "sabendo que esta é uma língua de modalidade espaço visual e a língua portuguesa de modalidade oral-auditiva, há uma incompatibilidade de estruturação gramatical, ou dizendo melhor, são sistemas organizados distintamente”. (Rodrigues e Valente, 2011, p. 19), aumentando ainda mais a profundidade da profissão. Os mesmos autores afirmam, recorrendo em algum momento ao texto de Quadros:

É preciso que o intérprete tenha excelente domínio da língua de partida, bem como da língua de chegada, que ele reconheça as diferentes intenções discursivas do indivíduo e tenha a capacidade de perceber certas sutilezas semânticas e pragmáticas na lingua-fonte (a de partida) e saber como expressá-las na língua alvo (a de chegada). (Quadros, 2007). Além de assimilar o que ouve e fazer a acomodação em sua mente, o intérprete deve processar a informação, o que, nesse caso, significa julgar qual sinalização da Libras corresponde a dada sentença do português. É uma tomada de decisão que acontece rapidamente.

$\mathrm{O}$ intérprete está para intermediar um processo interativo que envolve determinadas intenções conversacionais e discursivas. Nessas interações o intérprete tem a responsabilidade pela veracidade e fidelidade das informações. Assim, a ética deve estar na essência desse profissional e permear todas as suas decisões no momento de sua atuação. (Valente \& Rodrigues, 2011, p. 20, p. 21, p. 22).

Aparentando-se, para muitos, como uma profissão exigente, e de fato o é, o que parece é que a luta por direitos e reconhecimento jamais cessará. Segundo Albres $^{9}$ (citado por Araújo),

Os debates sobre este profissional eram reivindicações dos próprios surdos, embora ficava ainda em segundo plano, visto que a educação em uma perspectiva inclusiva estava começando a despontar e só no fim dos anos 90 que fortaleceu o movimento do qual demandava intérpretes de Libras em salas de aulas nas escolas comuns para mediar os alunos surdos, os professores e os colegas ouvintes. (Araújo, 2015, p. 159).

Além da morosidade na legislação (a favor da Libras e da inclusão) - e da velocidade nas legislações em contrário, a parceria com os surdos pareceu diminuir - houve aqueles que dissessem que os intérpretes dos surdos para "ganhar dinheiro" e a profissionalização do cargo enfrentou ainda outras discussões, até chegar melhor ao entendimento da população geral. Conforme Rodrigues e Valente,

O domínio da Libras, ser filho de surdos, ou professor de surdos, nada disso garante, por si só, que alguém possa ser intérprete. É preciso, na verdade, que haja uma conjunção de características que envolvem, além do conhecimento profundo da estrutura das línguas envolvidas e responsabilidade de manter-se fiel e neutro em relação ao objeto de interpretação, o conhecimento cultural suficiente da língua-alvo e da língua-fonte para fazer as devidas adaptações linguísticas de cunho idiomático e culturas. Aí entrecruzam habilidades linguísticas próprias e inferências que ocorrem durante o próprio ato interpretativo que levam intérpretes a usarem diferentes recursos para expressar os mais diversos significados, seja nas palavras, em nível lexical, ou nas frases, em nível sintático. (Rodrigues \& Valente, 2011, p. 19).

Ser intérprete de libras envolve ainda aderir à ética necessária a profissão. Nesse ponto, é importante, mencionar o Registro dos Intérpretes para Surdos - em 28-29 de janeiro de 1965, Washington, EUA, que foi traduzido originalmente do Interpreting for Deaf People, Stephen (ed.) USA por Ricardo Sander. As adaptações dos Representantes dos Estados Brasileiros, aprovadas por ocasião do II Encontro Nacional de Intérpretes - Rio de Janeiro/RJ/Brasil - 1992, foram incorporadas. É recomendável, para aqueles que querem ingressar ou que já estão na carreira, conhecê-lo. O documento pode ser encontrado na íntegra nas páginas 31 a 33 da obra O tradutor intérprete de língua de sinais e de sinais e língua portuguesa (2002), de Ronice Müller de Quadros.

${ }^{9}$ Aquino, N. A. de. Intérprete Educacional políticas e práticas em sala de aula inclusiva. Harmonia, 2015. 
Ser tradutor/intérprete, por tudo o que já foi apresentado, não é uma tarefa fácil. As dificuldades aumentam quando o ambiente de interpretação é o educacional. Para Quadros (2007), “seria impossível atender às exigências legais que determinam o acesso e a permanência do aluno na escola observando-se suas especificidades sem a presença de Intérpretes de Línguas de Sinais." (Quadros, 2007, p. 59).

A importância das questões éticas da profissão se redobra neste ambiente e a definição dos papeis de cada servidor da escola é extremamente necessária, como se o estudante surdo fosse responsabilidade do intérprete, e não do professor, como os demais.

Muitas vezes, o papel do intérprete em sala de aula acaba sendo confundido com o papel do professor. Os alunos dirigem questões diretamente ao intérprete, comentam e travam discussões em relações aos tópicos abordados com o intérprete, e não com o professor. O próprio professor delega ao intérprete a responsabilidade de assumir o ensino dos conteúdos desenvolvidos em aula ao intérprete. Muitas vezes, o professor consulta o intérprete a respeito do desenvolvimento do aluno surdo, como sendo ele a pessoa mais indicada a dar um parecer a respeito. (Quadros, 2007, p. 60).

A autora questiona: se fosse papel do intérprete assumir as responsabilidades do ensino, porque não o remunerar como professor, além de intérprete? E continua:

E se estiverem assumindo a função de professores, por que estariam sendo contratados como intérpretes? Considerando tais questões, poder-se-ia determinar que o intérprete assumirá somente a função de intérprete, que em si já basta, e caso seja requerido um professor que domine língua de sinais, que este seja contratado como tal. (Quadros, 2007, p. 61)

Na inclusão do aluno surdo, é necessário frisar que o papel do intérprete por si só não elimina todas as barreiras. É necessário repensar as práticas pedagógicas, avaliativas e metodologias:

Os alunos surdos participam das aulas visualmente e precisam de tempo para olhar para o intérprete, olhar para as anotações no quadro, olhar para os materiais que o professor estiver utilizando em aula. Também, deve ser resolvido como serão feitas as anotações referentes ao conteúdo, uma vez que o aluno surdo manterá sua atenção na aula e não disporá de tempo para realizá-las. (Quadros, 2007, p. 61).

\section{Metodologia}

O presente estudo foi realizado a partir da pesquisa bibliográfica, baseada nos estudos de pesquisadores surdos e ouvintes, sobre a educação de surdos, e documental, com referência à legislação citada, conforme apresentado na seção anterior.

Posteriomente, foram relacionadas todas as Instituições de Ensino Superior do Estado de Minas Gerais, via Sistema de Informação ao Cidadão do Governo Federal (e-Sic), o número de alunos e de profissionais intérpretes de cada uma, para proposição da discussão e dos resultados.

Optou-se, então, por fazer um estudo de caso com base nessas instituições. Segundo Pereira et al, "um estudo de caso é uma descrição e análise, a mais detalhada possível, de algum caso que apresente alguma particularidade que o torna especial. Sob o título EC se incluem muitos estudos que forma uma gama de variedades” (2018, p. 65). Assim, para os autores,

[...] um caso para ser considerado como tal, deve ser um fenômeno que possui alguma característica especial ou diferencial que o tira do "lugar comum". [...] Como isso teria acontecido? Que variáveis interferiram no fenômeno? As questões vão surgindo e na medida em que o pesquisador busca por respostas focadas no acontecimento, as respostas vão surgindo. (Pereira et al, 2018, p. 65).

A abordagem, a partir da coleta dos números e sua interpretação, proponde se para o estudo qualitativo. Para Pereira et al, "estes métodos geram conjuntos ou massas de dados que podem ser analisados por meio de técnicas matemáticas como é o 
caso das porcentagens, estatísticas e probabilidades, métodos numéricos, métodos analíticos e geração de equações e/ou fórmulas matemáticas aplicáveis a algum processo" (2018, p. 69), conforme pode ser observado no quadro da seção a seguir.

No entanto, os autores resgatam a fala de Yin (2015), que "considera que os métodos qualitativos e quantitativos não se excluem e podem ser importantes se complementando e permitindo um melhor entendimento dos fenômenos em estudo" (Pereira et al, 2018, p. 69).

\section{Resultados e Discussão}

A seção seguinte apresenta os resultados da pesquisa, demonstrando que as Instituições de Ensino Superior apresentam grandes defasagens no que diz respeito ao seu quadro de servidores com aptidão para tornar os órgãos acessíveis à comunidade surda, de acordo com os dados do Instituto Brasileiro de Geografia e Estatística - IBGE.

\subsection{Apresentação dos dados coletados}

Após a coleta, os dados foram sistematizados no quadro abaixo, que demonstra a quantidade de profissionais tradutores intérpretes em cada Instituição Federal de Ensino de Minas Gerais, levando-se em conta a quantidade de alunos, de unidades universitárias (campi, centros acadêmicos ${ }^{10}$ ). Conforme dito acima, se a instituição oferece cursos superiores (como é o caso de todas as pesquisas) a formação causa influência nas escolhas tradutórias e consequentemente, na qualidade da interpretação. Deve-se considerar ainda que a quantidade de alunos não reflete exatamente a quantidade de usuários surdos dessas instituições, pois estes últimos são também alvos de projetos de extensão, ou possuem familiares surdos, e os próprios surdos não matriculados podem fazer uso de biblioteca e setores como Informações à Comunidade, secretaria e protocolo.

A terceirização de profissionais de carreira federal também acarreta na perda de qualidade desses serviços, não apenas em função do profissional, mas, sobretudo, em função da carreira construída ao longo dos anos, da experiência acumulada e do vínculo com a instituição.

De acordo com dados do CENSO 2010 do IBGE, 9.717.318 pessoas possuem deficiência auditiva, que abrange a surdez. Na estimativa de 2020, a população do Brasil chegou à 211,8 milhões de habitantes. Essa conta indica, de modo geral, que pelo menos $4,6 \%$ da população tem problemas auditivos e devem ser atendidos pelas leis supracitadas.

Tendo como base esses números, o quadro abaixo nos ajuda a identificar se o atendimento nas unidades de ensino federais de Minas Gerais é suficiente ou satisfatório. Os dados foram obtidos por meio do portal da Controladoria Geral da União (Fala.BR), informados pelas próprias unidades. Os nomes das unidades encontram-se nas notas de finali.

\footnotetext{
${ }^{10}$ Nesta contagem foi incluída a reitoria de cada órgão, além das unidades acadêmicas, porém não foram consideradas as Escolas de Educação à Distância (pelas diferenças em suas estruturas), embora seus alunos tenham sido contados, quando informados pela instituição.
} 
Quadro 1: Quantitativo de intérpretes de Libras e estudantes por unidade.

\begin{tabular}{|c|c|c|c|c|c|c|c|c|c|c|}
\hline 恚 & 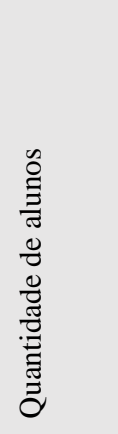 & 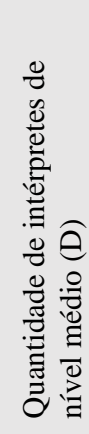 & 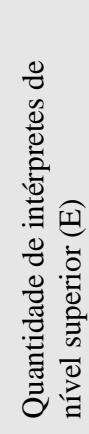 & 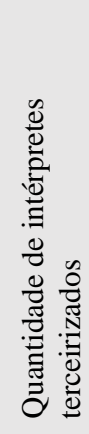 & 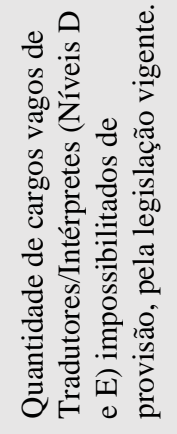 & 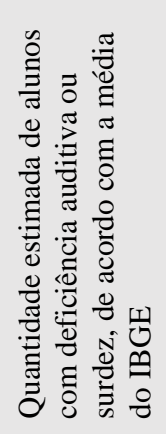 & 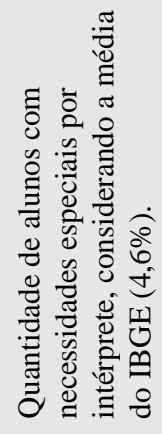 & 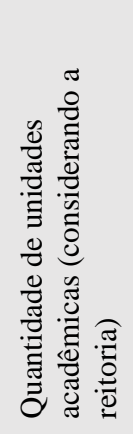 & 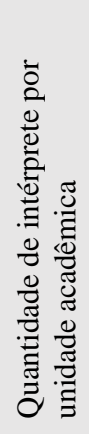 & 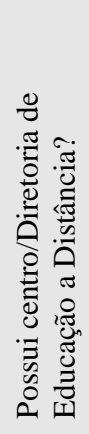 \\
\hline CEFET-MG & & & & & & & & 12 & & Sim \\
\hline IFMG & 17266 & 14 & 0 & 0 & 2 & 37,53 & 2,68 & 20 & 0,70 & Sim \\
\hline IFNMG & 26372 & 9 & 0 & 0 & 0 & 57,33 & 4,41 & 12 & 0,75 & Sim \\
\hline IFSudesteMG & 11320 & 9 & 0 & 3 & 1 & 24,60 & 2,05 & 11 & 0,91 & Sim \\
\hline IFSulMG & 43000 & 7 & 0 & $1^{11}$ & 0 & 93,47 & 11,68 & 9 & 0,88 & Sim \\
\hline IFTM & 12982 & 9 & 0 & 0 & 0 & 28,22 & 3,13 & 13 & 0,69 & Não \\
\hline UNIFAL & 6459 & 4 & 0 & 0 & 0 & 14,04 & 4,68 & 4 & 1 & Sim \\
\hline UNIFEI & 7770 & 0 & 0 & 3 & 0 & 16,89 & 5,63 & 3 & 1 & Sim \\
\hline UFJF & $20245^{12}$ & 13 & 0 & 0 & 0 & 44,01 & 3,38 & 12 & 1,08 & Sim \\
\hline UFLA & 14139 & 1 & 0 & 0 & 1 & 30,73 & 30,73 & 3 & 0,33 & Sim \\
\hline UFMG & 44039 & 8 & 0 & 9 & 0 & 95,73 & 5,63 & 5 & 3,4 & Sim \\
\hline UFOP & 14263 & 4 & 0 & 0 & 2 & 31 & 7,75 & 4 & 1 & Sim \\
\hline UFSJ & 15383 & 7 & 0 & 0 & 0 & 33,44 & 4,77 & 7 & 1 & Sim \\
\hline UFU & 32683 & 10 & 0 & 1 & 0 & 71,05 & 6,45 & 7 & 1,57 & Sim \\
\hline UFV & 11025 & 7 & $1^{13}$ & 2 & 2 & 23,96 & 2,66 & 7 & 1 & Sim \\
\hline UFVJM & 9648 & 5 & 0 & 0 & 0 & 20,97 & 4,19 & 6 & 1,16 & Sim \\
\hline UFTM & 6361 & 4 & 2 & 0 & 1 & 13,82 & 2,30 & 7 & 0,85 & Sim \\
\hline
\end{tabular}

Fonte: Autores (2021).

O quadro demonstra a defasagem de profissionais em todas as instituições, com campus/unidades onde nem sequer há a presença do intérprete de Libras (quando a penúltima coluna apresentou um resultado abaixo de 1), o que pode inviabilizar a política de inclusão da comunidade surda, bem como faz-nos questionar a razoabilidade do decreto 10.185 de 20 de dezembro de 2019, citado na primeira seção.

A própria FEBRABILS demonstrou supresa com tal ato do Poder Executivo e manifestou-se:

\footnotetext{
${ }^{11}$ Segundo o Instituto, o Tradutor/Intérprete é contratado como professor substituto.

${ }^{12}$ Segundo a Universidade, esse número corresponde aos alunos da graduação. Os da pós-graduação não estão contabilizados ou incluídos nesse número.

${ }^{13}$ Segundo a Universidade, esse cargo não tem relação com a Língua de Sinais, de modo que não foi considerado no cálculo da coluna 9.
} 
[...] isso significa, pessoas surdas em instituições de ensino sem a presença de profissionais qualificados para o atendimento, situação essa que é contrária a LBI, pois é responsabilidade do Estado a manutenção e garantia de políticas públicas que possam assegurar o direito linguístico e a acessibilidade da pessoa surda (Lei 13.146- LBI Cap. IV. Att 28 XVIII Parágrafo II). Temos conhecimento de pessoas que possuem conhecimentos rudimentares em Libras e estão atendendo surdos em sala de aula de instituições de ensino superior, recebendo uma bolsa para sua atuação, o que é grave. Sabemos de diversos intérpretes atuando sozinhos por longos períodos, sem horas de preparação para realizar sua atividade e sem atuação em equipe garantida. O que gera prejuízos imensuráveis, físicos e psicológicos para os profissionais e para os alunos que tem seu direito garantido por lei descumpridos.

\section{Conclusões}

A língua de sinais foi uma conquista para as populações surdas, historicamente excluídas, escondidas pelas famílias ou tratadas como doentes. $\mathrm{O}$ conceito de normal/anormal surge como sistema capitalista, que só busca a maior produtividade e o lucro, o que foi determinante para legitimar esse tratamento a essas populações, a partir do paradigma biológico.

O termo "surdo-mudo" não é o mais adequado, pois a grande maioria dos surdos não é muda, pois, como nós, eles são dotados de voz, mas utilizam a Libras, que é uma língua visual, que utiliza movimentos com as mãos e expressões faciais, diferentemente das línguas orais-auditivas.

O reconhecimento da Língua Brasileira de Sinais - Libras como língua oficial, a partir da lei 10.436/2002, possibilitou ao povo surdo acesso ao conhecimento, à arte, à ciência, e aos diversos espaços sociais. Vygotsky (2000, citado por Ferreira et al), afirma que língua e pensamento caminham juntos, um depende do outro para coexistir.

O processo de difusão da Libras encontrou diversas dificuldades. Desde a compreensão (errônea) de que a Libras era uma língua universal, ou derivada do português, ou composta apenas por um alfabeto manual, ou uma linguagem e não uma língua, além da extensão do território nacional e do afastamento das comunidades surdas.

Nesse sentido, foi importante a criação do INES em 1857, a partir da chegada do professor surdo francês Ernest Huet ao Brasil. A pesquisadora Karin Strobel, no entanto, afirma que a educação de surdos no Brasil começou ainda próximo do ano 1500, com o médico Girolamo Cardano e o monge beneditino Pedro Ponce de Leon, que criou uma escola para educação de surdos. Importante também citar o reverendo Tomas Gallaudet (1787-1851), que trouxe da França o professor surdo Laurent Clerc, para fundar as escolas de surdos na América.

No entanto, acontecido em 1880, o Congresso de Milão trouxe retrocesso para a educação de surdos, ao preferir o uso da língua falada, em relação ao uso da língua gestual, o ensino deveria ser oralista, e os novos alunos separados daqueles que já tinham contato com as línguas de sinais. A língua oral não é a língua materna dos surdos, o que foi significou uma imposição de que os surdos fossem tratados e se comportassem como ouvintes.

A Declaração de Salamanca (1994), a Constituição Brasileira (1988) e outros dispositivos legais como o Estatuto do Deficiente permitiram que a inclusão dos estudantes com necessidades específicas em escolas regulares (não em escolas especiais, que os segregavam) pudesse acontecer com os devidos cuidados, com destaque ao decreto 6.094/2007 e a Política Nacional de Educacional de Educação Especial na Perspectiva da Educação Inclusiva.

Com essa mudança estrutural, alunos com os mais diversos tipos de deficiência foram incluídos nas salas de aula regulares, promovendo de fato a chamada "inclusão", que modificou a vida de muitos deles, e lhes propiciou muitas oportunidades. Nesse aspecto, é significativa a fala de Paula de Freire sobre aceitar e respeitar a diferença.

Para que os surdos matriculados em escolas regulares tivessem o atendimento adequado, foi promulgado o decreto 5.626/2005, que estabelece uma série de determinações, inclusive, a de que as Instituições Federais de Ensino devem prover a escola com intérpretes de libras. Ainda assim, e conforme comprovado no quadro apresentado, faltam intérpretes nas instituições. 
Decretos posteriores ao impeachment (em 2018 e 2019) proibiram a nomeação de novos intérpretes na rede federal e extinguiram os cargos, prejudicando o atendimento aos surdos, excluindo-os, num movimento semelhante ao congresso de Milão.

Os intérpretes terceirizados não têm a mesma remuneração e muitas vezes a mesma experiência e formação dos profissionais efetivos, além do que não é fácil contratá-los nas instituições, especialmente em cidades menores. A comunidade surda, em 2019, divulgou nota de repúdio ao decreto 10.185/2019. Sem dúvida, houve um retrocesso na profissão dos tradutores/intérpretes, levando a profissão ao voluntarismo e à precarização, induzindo pessoas que não têm formação adequada e nem conhecimento do código de ética da profissão a aderi-la.

Em 2021, após ser aprovada no final de 2020 na Câmara dos Deputados, a regulamentação da profissão dos intérpretes vai ao Senado Federal, com novas proposições que consideram a formação do profissional (principalmente aquele que interpreta em nível superior e pós-graduação), que deve ter conhecimento suficiente para tal, da quantidade de horas trabalhadas na semana, considerando que é um trabalho de esforço físico e mental simultâneo, e por isso mesmo, a necessidade de revezamento no ato tradutório.

Há ainda a questão dos intérpretes em sala de aula, que têm sua função confundida com as do professor, sendo, algumas vezes, responsabilizados pela aprendizagem do aluno surdo, e não pela mediação da comunicação como deveria ser. O professor com estudantes surdos precisa repensar suas práticas, porque mesmo com a presença do intérprete, ela por si só não elimina todas as dificuldades que um aluno surdo possa apresentar.

O quadro elaborado e apresentado na seção 4 demonstra a defasagem de intérpretes nas instituições de ensino da rede federal do Estado de Minas Gerais, sendo que, com os decretos em vigência, a dificuldade em provê-los é muito maior. Os itens em amarelo chamam a nossa atenção para as quantidades insuficientes. Foi considerada na coluna 11 se existem alunos da Educação a Distância, porque esses também dependem de serviços tradutórios.

A coluna 7 mostra quantos alunos com surdez ou deficiência auditiva a instituição pode ter (de acordo com a estatística do IBGE) e quantos intérpretes existem para atendê-los (Coluna 8). Importante salientar que esses surdos podem estar em turmas diferentes. Esses números refletem as verdadeiras possibilidades de inclusão da instituição. A coluna 10 demonstra quantos intérpretes há para cada unidade acadêmica (reitoria e campi), mostrando que há instituições com menos de 1 intérprete por unidade.

As células destacadas no quadro da seção anterior explicitam como a inclusão da pessoa surda ainda está deficiente nas instituições de ensino.

É importante que a comunidade surda, juntamente com os profissionais da educação se unam para que essa situação se reverta, e que os avanços obtidos a partir de 2007 não sejam desfeitos, seja a partir da sobrecarga e precarização do serviço de intérpretes, bem como novos dispositivos legais, como a volta de escolas especiais ou classes especiais.

As questões aqui trazidas servem ainda de ponto de partida para outros questionamentos, como aqueles que envolvem o fazer docente diante de um estudante surdo, da formação de intérpretes profissionais, da importância das políticas públicas para a inclusão, da representatividade das pessoas surdas nos espaços escolares e se sua formação é eficaz e de que forma a terceirização pode contribuir para o sucateamento do ensino público.

A inclusão é a forma de uma sociedade justa, democrática, igualitária. Assim como os avanços devem ser comemorados não só por aqueles que são beneficiados, os retrocessos também devem ser denunciados e combatidos. Os resultados obtidos e tabulados demonstram que há muito o que fazer e muito o que lutar por esse ideal. A inclusão será sempre uma luta. A luta é de todos! 


\section{Referências}

Araujo, B. R. N. (2015). A historicidade do TILS - Tradutor e Intérprete de Língua de Sinais: Do anonimato ao reconhecimento. Aquidauana: Albuquerque Revista de História. 7, 150-163.

Azevedo, L. M. C. (2018). Saúde Ocupacional e Ergonomia na atuação do Tradutor Intérprete de Libras. Monografia apresentada ao Bacharelado em Letras Libras da UFSC. 2018, 52p.

Baalbaki, A., \& Caldas, B. (2011). Impacto do Congresso de Milão Sobre as Línguas dos Sinais. Rio de Janeiro: Cadernos do XV Congresso Nacional de Linguística e Filologia, XV. 2, CiFEFil.

Controladoria Geral Da União. Fala.BR. (2021). Plataforma Integrada de Ouvidoria e Acesso à Informação. https://falabr.cgu.gov.br/publico/Manifestac ao/SelecionarTipoManifestacao.aspx?ReturnUrl=\%2fPrincipal.aspx.

Febrapils. Documentos. (2021). Nota Técnica N²/2017. http://febrapils.org.br/documentos.

Febrapils. Documentos (2021). Nota da Febrapils Sobre o Decreto 10.185. http://febrapils.org.br/documentos.

Ferreira, W. M., Nascimento, S. P. F., \& Pitanga, Â. F. (2014). Dez Anos da Lei da Libras: Um Conspecto dos Estudos Publicados nos Últimos 10 Anos nos Anais das Reuniões da Sociedade de Química. Química Nova na escola. 36, 185-193.

Freire, P. (1992). Pedagogia da Esperança. Paz e Terra.

Gesser, A. (2009). Libras? Que língua é essa? Crenças e Preconceitos em torno da língua de sinais e da realidade surda: Parábola Editorial.

IBGE (2010). Censo 2010. Estimativas de Gênero. Indicadores: Deficiência Auditiva. https://www.ibge.gov.br/apps/snig/v1/?loc=0\&cat=-1,-2,$3,128 \&$ ind $=4643$.

IBGE (2020). Notícias. IBGE divulga estimativa da população dos municípios para 2020. https://agenciadenoticias.ibge.gov.br/agencia-sala-de-imprensa/2013agencia-de-noticias/releases/28668-ibge-divulga-estimativa-da-populacao-dos-municipios-para-2020\#: :text=IBGE\%20divu lga\%20estimati va\%20da\%20po pula $\%$ C3\%A7\%C3\%A3o\%20dos\%20munic\%C3\%ADpios\%20para\%202020,-Editoria\%3A\%20E stat\%C3\%ADsticas\%20Sociais\&text= O $\% 20 \mathrm{IBGE} \% 2$ 0divulg a\%20hoje $\% 20 \mathrm{as}, 77 \% 25 \% 20 \mathrm{em} \% 20$ rela\%C3\%A7\%C3\%A3o\%20a\%202019.

IFNMG, Canal do Youtube. (2020). Roda de Conversa. O protagonismo e o empoderamento das pessoas com deficiência.

Jornal De Brasília. (2020). MEC vai receber denúncias de recusa de matrículas após decreto sobre educação especial. https://jornaldebrasilia.com.br/brasil/mecvai-receber-denuncias-de-recusa-de-matriculas-apos-decreto-sobre-educacao-especial/.

Kohan, W. O. (2019). Paulo Freire e o valor da igualdade em Educação. Revista Educação e Pesquisa, 45, e. 201600.

MEC/SEESP. (2008). Política Nacional de Educação Especial na Perspectiva da Educação Inclusiva. MEC/SEESP.

Monteiro, M. S. (2006). História dos Movimentos dos Surdos e o Reconhecimento da Libras no Brasil. Campinas: Educação Temática Digital, 7. 292-302, jun.2006.

Pagura, R. (2003). A interpretação de conferências: Interface com a tradução escrita e implicações para a formação de intérpretes e tradutores. São Paulo: Revista D.E.L.T.A., 19:Especial, 2003, 209-236.

Pereira, A. S. et al. (2018). Metodologia da pesquisa científica. UFSM.

Petição Pública. (2021). Tradutor de intérprete de Libras nível E. https://peticaopublica.com.br/pview.aspx?pi=BR94155.

Pinheiro, R. C. (2017). Contribuições do Programa Etnomatemática Para o Desenvolvimento da Educação Financeira de Alunos Surdos Que se Comunicam em Libras. Dissertação de Mestrado apresentada ao Mestrado Profissional em Educação Matemática. Ouro Preto: UFOP, 2017.284 p.

Presidência Da República. (1988). Casa Civil. Subchefia para Assuntos Jurídicos. Constituição da República Federativa do Brasil de 1988. http://www.planalto.gov.br/ccivil_03/constituicao/constituicao.htm.

Presidência Da República. (1996). Casa Civil. Subchefia para Assuntos Jurídicos. LEI N ${ }^{\circ} 9.394$, de 20 de dezembro de 1996. http://www.planalto.gov.br/ccivil_03/leis/19394.htm.

Presidência Da República. (2002). Casa Civil. Subchefia para Assuntos Jurídicos. LEI No 10.436 , DE 24 DE ABRIL DE 2002. http://www.planalto.gov.br/ccivil_03/leis/2002/110436.htm\#: :text=LEI\%20N\%C2\%BA\%2010.436\%2C\%20DE\%2024\%20DE\%20ABRIL\%20DE\%202002. \&text=Disp\%C3\%B5e\%20sobre\%20a\%20L\%C3\%ADngua\%20Brasileira,Art.

Presidência Da República. (2005). Casa Civil. Subchefia para Assuntos Jurídicos. DECRETO No 5.626, DE 22 DE DEZEMBRO DE 2005. http://www.planalto.gov.br/ccivil_03/_ato2004-2006/2005/decreto/d5626.htm.

Presidência Da República. (2007). Casa Civil. Subchefia para Assuntos Jurídicos. DECRETO No 6.094, DE 24 DE ABRIL DE 2007. http://www.planalto.gov.br/ccivil_03/_ato2007-2010/2007/decreto/d6094.htm.

Presidência Da República. (2018). Secretaria Geral. Subchefia para Assuntos Jurídicos. DECRETO No 9.262, DE 9 DE JANEIRO DE 2018. https://www.planalto.gov.br/ccivil_03/_ato2015-2018/2018/decreto/D9262.htm.

Presidência Da República. (2019). Casa Civil. Subchefia para Assuntos Jurídicos. DECRETO No 10.185, DE 20 DE DEZEMBRO DE 2019. Disponível em http://www.planalto.gov.br/ccivil_03/_ato2019-2022/2019/decreto/D10185.htm. 
Research, Society and Development, v. 10, n. 10, e514101019226, 2021

(CC BY 4.0) | ISSN 2525-3409 | DOI: http://dx.doi.org/10.33448/rsd-v10i10.19226

Presidência Da República. (2019). Secretaria Geral. Subchefia para Assuntos Jurídicos. DECRETO No 10.185, DE 20 DE DEZEMBRO DE 2019. Disponível em http://www.planalto.gov.br/ccivil_03/_ato2019-2022/2019/decreto/D10185.htm.

Presidência Da República. (2020). Secretaria-Geral. Subchefia para Assuntos Jurídicos. DECRETO No 10.502, DE 30 DE SETEMBRO DE 2020. http://www.planalto.gov.br/ccivil_03/_ato2019-2022/2020/decreto/D10502.htm\#: :text=DECRETO\%20N\%C2\%BA \%2010.502\%2C\%20D E\%2030\%20 DE\% 20SETEMBRO\%20DE\%202020\&text=Institui\%20a\%20Pol\%C3\%ADtica\%20Nacional\%20de,Aprendizado\%20ao\%20Longo\%20da\%20Vida.

Quadros, R. M. (2002). O tradutor interprete de língua de sinais e de sinais e língua portuguesa. Programa Nacional de Apoio à Educação de Surdos. Brasília: MEC/SEESP.

Senado Federal. (2020). Projeto de Lei $\mathrm{n}^{\circ} 5614$ de 2020. https://legis.senado.leg.br/sdleg-getter/documento?dm=8915783\&ts=1609866532751 \&disposition=inline.

Strobel, K. (2009). História da Educação de Surdos. UFSC, 2009.

Supremo Tribunal Federal. (2021). A Constituição e o Supremo. https://constituicao.stf.jus.br/dispositivo/cf-88-parte-1-titulo-8-capitulo-3-secao-1-artigo-208.

Valente, F., Rodrigues, C. S. (2011). Intérprete de Libras. IESDE BRASIL.

VOX Intérpretes. (2016). O drama dos "terps" os intérpretes de guerra. Publicado em 29/05/2016. https://voxinterpretes.com.br/2016/03/29/o-drama-dos-terpsos-interpretes-de-guerra/.

\footnotetext{
i Nome das Instituições Federais de Ensino de Minas Gerais

Centro Federal de Educação Tecnológica de Minas Gerais (CEFET-MG)

Instituto Federal de Minas Gerais (IFMG)

Instituto Federal do Norte de Minas Gerais (IFNMG)

Instituto Federal do Sudeste de Minas (IFSUDESTEMG)

Instituto Federal do Sul de Minas (IFSULMG)

Instituto Federal do Triângulo Mineiro (IFTM)

Universidade Federal de Alfenas (UNIFAL)

Universidade Federal de Itajubá (UNIFEI)

Universidade Federal de Juiz de Fora (UFJF)

Universidade Federal de Lavras (UFLA)

Universidade Federal de Minas Gerais (UFMG)

Universidade Federal de Ouro Preto (UfOP)

Universidade Federal de São João Del-Rei (UFSJ)

Universidade Federal de Uberlândia (UFU)

Universidade Federal de Viçosa (UFV)

Universidade Federal dos Vales do Jequitinhonha e Mucuri (UFVJM)

Universidade Federal do Triângulo Mineiro (UFTM)
} 